\title{
Acetoaminophen-induced accumulation of 8-oxodeoxyguanosine through reduction of Ogg1 DNA repair enzyme in $\mathrm{C} 6$ glioma cells
}

\author{
Jie Wan' ${ }^{2}$, Myung-Ae $B a e^{3}$ and \\ Byoung-Joon Song ${ }^{1,4}$
}

\author{
${ }^{1}$ Laboratory of Membrane Biochemistry and Biophysics \\ National Institute on Alcohol Abuse and Alcoholism \\ NIH, 12420 Parklawn Drive, Rockville, MD 20852, USA \\ ${ }^{2}$ Department of Pharmacology and Toxicology \\ University of Utah Medical School \\ Salt Lake City, UT, USA \\ ${ }^{3}$ Center for Biological Modulator \\ Korea Research Institute on Chemical Technology \\ Daejeon, Korea \\ ${ }^{4}$ Corresponding author: Tel, 301-496-3985; \\ Fax, 301-594-3113; E-mail, bjs@mail.nih.gov
}

Accepted 7 January 2004

Abbreviation: APAP, acetaminophen; DHR-123, dihydrorhodamine123; NAPQI, N-acetyl-p-benzoquinoneimine; ROS/RNS, reactive oxygen and nitrogen species; 2'-dG, 2'-deoxyguanosine; 8-oxodG, 8-oxo-deoxyguanosine

\begin{abstract}
Large doses of acetaminophen (APAP) could cause oxidative stress and tissue damage through production of reactive oxygen/nitrogen (ROS/RNS) species and quinone metabolites of APAP. AIthough ROS/RNS are known to modify DNA, the effect of APAP on DNA modifications has not been studied systematically. In this study, we investigate whether large doses of APAP can modify the nuclear DNA in C6 glioma cells used as a model system, because these cells contain cytochrome P450-related enzymes responsible for APAP metabolism and subsequent toxicity (Geng and Strobel, 1995). Our results revealed that APAP produced ROS and significantly elevated the 8-0x0deoxyguanosine (8-oxodG) levels in the nucleus of C6 glioma cells in a time and concentration dependent manner. APAP significantly reduced the 8oxodG incision activity in the nucleus by decreasing the activity and content of a DNA repair enzyme, Ogg1. These results indicate that APAP in large doses can increase the 8-oxodG level
\end{abstract}

partly through significant reduction of $0 \mathrm{gg} 1$ DNA repair enzyme.

Keywords: acetaminophen; cytochrome P450 CYP2E1; DNA repair enzymes

\section{Introduction}

Acetaminophen (APAP, paracetamol, $N$-acetyl-p-aminophenol) is one of the most frequently used analgesics/antipyretics and generally considered safe under therapeutic doses (Thomas, 1993). However, large dosage and long term APAP addictive usage were also reported (Shayiq et al., 1999). When APAP is consumed in large doses, it is known to damage to the liver, kidney and other organs (Thomas, 1993). The APAP-induced toxicity can take place especially when the levels of tissue anti-oxidants such as glutathione are low after fasting or chronic alcohol consumption and/or inadequate nutritional intake or starvation (Seeff et al., 1986; Whitcomb and Block, 1994). APAP was shown to produce reactive oxygen and nitrogen species (ROS/RNS) and reactive metabolites in experimental animals or cultured cells (Adamson and Harman, 1993; Lores Arnaiz et al., 1995) and that cellular DNA can be modified by ROS/RNS, lipid peroxides, or free radical metabolites (Ames, 1989; Wiseman and Halliwell, 1996). Therefore, it is possible that large doses of APAP could modify cellular DNA. However, this question was not systematically evaluated.

In mammalian cells, oxidative DNA damage is mainly repaired via the base excision repair pathway (Wood, 1996), although recent studies in yeast showed that nucleotide excision repair pathway (Scott et al., 1999) is also involved in the repair of 8 -oxodG in DNA. Base excision repair is initiated by the removal of the damaged base by a glycosylase. The resulting abasic site is further processed by AP lyase, AP endonuclease, DNA polymerase and a DNA ligase (Wood, 1996; Boiteux and Radicella, 2000). This process replaces just one nucleotide, finally filling the gap (Krokan et al., 1997). A gene called Ogg1 (8-oxoguanine DNA glycosylase) has been recently cloned in various species including human and rodents (Arai et al., 1997; Prieto Alamo et al., 1998; Tani et al., 1998). This gene product, Ogg1 protein was shown 
to exhibit DNA glycosylase/AP lyase activity, which removes 8-oxodG from damaged DNA by base excision repair. Furthermore, high levels of 8-oxodG were detected in the genome with significantly elevated spontaneous mutation rates in nonproliferative tissues in homozygous ogg $1^{-1-}$ null mice (Minowa et al., 2000). These reports strongly suggest that base excision repair of 8 -oxodG by Ogg1 protein protects the genome from the ROS-induced oxidative damage in both prokaryotes and eukaryotes. The aim of this current study was to investigate whether large doses of APAP alter the level of 8-oxodG in the nucleus through ROS/RNS production and/or potential modulation of Ogg1 DNA repair enzyme. In the current study, we used C6 glioma cells as a model, because these cells contain catalytically active cytochrome P450 related enzymes such as CYP2E1 and CYP1A2, both of which are important in APAP metabolism and subsequent toxicity (Geng and Strobel, 1993; 1995; Bae et al., 2001).

\section{Materials and Methods}

\section{Materials}

Rabbit anti-mouse Ogg1 antibody was purchased from Alpha Diagnostic Internationals (San Antonio, TX). Horseradish peroxidase conjugated goat antirabbit IgG was from Amersham (Buckinghamshire, England). Nuclease P1, bacterial alkaline phosphatase, 8-oxodG, 2'-dG, glutathione (GSH), DMSO and dihydrorhodamine 123 (DHR-123) were from Sigma (St. Louis, MO).

\section{Cell culture and determination of ROS/RNS production}

C6 cells, grown in 96-well microtiter plates (Bae et al., 2001), were incubated for indicated times with or without APAP in the presence of $25 \mathrm{mM}$ DHR-123 in the culture medium as described (Muijsers et al., 2000). After incubation, DHR-123 conversion to rhodamine-123 was measured by fluorometric analysis at excitation/emission wavelengths of 485 and $530 \mathrm{~nm}$, respectively (SpectraFluor Plus, Tecan Inc., Research Triangle Park, NC).

\section{Determination of $\mathbf{G S H}$ concentration}

Cells, grown to about $80 \%$ confluence in plastic culture dishes (150 $\mathrm{mm}$ diameter), were treated with 5 $\mathrm{mM}$ APAP for indicated times. Treated cells were harvested by centrifugation at 2,000 $\mathrm{g}$ for $2 \mathrm{~min}$ and resulting cell pellets were sonicated in a cell lysis buffer (Bae et al., 2001). GSH concentration in the whole cell extracts was determined as described
(Dimova et al., 2000) using a fluorometer (Bio-Rad VersaFluor). Excitation was determined at $360 \mathrm{~nm}$ while emission was measured at $440 \mathrm{~nm}$.

\section{Determination of 8-oxodG levels in the nuclear DNA}

C6 glioma cells were treated with different concentrations of APAP for indicated times, harvested, and washed with $1 \times$ PBS, before their extracts were used for measurement of protein content and enzyme activity. To isolate nuclear DNA, another batch of cell pellets was dissolved in the $1 \times \mathrm{M}-\mathrm{SHE}$ buffer (Croteau et al., 1997) and sonicated for $12 \mathrm{~s}$ with Branson Sonifier 250. Nuclear fractions were collected by centrifugation at $500 \mathrm{~g}$, suspended in a fresh M-SHE buffer, and re-centrifuged to obtain the final nuclear fractions. Nuclear DNA was then isolated by using a Puregene ${ }^{\circledR}$ DNA isolation kit (Gentra Systems, Inc, Minneapolis, MN) following the manufacturer's instruction. Isolated DNA was digested to nucleosides with nuclease $\mathrm{P} 1$ and alkaline phosphatase by the method of Lan et al. (2000). Levels of 8-oxodG and 2'-dG were determined with HPLC (Waters 625 LC pump, Milford, MA) following the method (Lan et al., 2000) except for the following modifications. An ESA Coulochem II detector (Chelmsford, MA) with potential sets at $850 \mathrm{mV}$ for guard cell, $380 \mathrm{mV}$ for 8-oxodG and $800 \mathrm{mV}$ for 2'-dG was used. The collected data were analyzed using EZChrom chromatography data system (Scientific Software, Inc., San Ramon, CA). The ratios of 8 -oxodG to $2^{\prime}-d G$ in the DNA sample were determined from the peak heights of the standards.

\section{Measurement of 8-0xodG incision activity}

Nuclear fractions were prepared as described (Croteau et al., 1997). The final extracts were re-suspended in a buffer containing $20 \mathrm{mM}$ Hepes-KOH $(\mathrm{pH} \mathrm{7.6)}$, $1 \mathrm{mM}$ EDTA, $2 \mathrm{mM}$ DTT, $300 \mathrm{mM} \mathrm{KCl}, 5 \%$ glycerol and $0.05 \%$ Triton $X-100$. The oligonucleotide containing an 8-oxodG (5'-GAACGACTGTG ${ }^{\text {oxo }}$ ACTTGACTGCTACTGAT-3') was the same as reported (Croteau et al., 1997) and purchased from the Midland Certified Reagent Company (Midland, TX). The incision activity was determined by the method as described (Souza-Pinto et al., 1999).

\section{Immunoblot analysis of rat $0 \mathrm{gg} 1$ protein in $\mathrm{C} 6$ cells}

Ogg1 protein level was determined by immunoblot analysis using the rabbit antibody against mouse Ogg1 (1:1,000 dilution) overnight, as described (Bae et al., 2001). The immunoreactive protein was recognized by the secondary antibody (goat anti-rabbit IgG 
conjugated with horse radish peroxidase, 1:1,000 dilution) using the Pierce Supersignal chemiluminescent substrate kit (Rockford, Illinois).

\section{Statistical analysis}

The signal density of 8-oxodG incision activity, Ogg1 protein content, or mRNA levels determined by RTPCR was quantified using $\mathrm{NIH}$ image $1.61(\mathrm{NIH})$. Statistical analysis was performed by Student's $t$ test (Statistica $3.0 \mathrm{~b}$ ) to determine the significance of difference between control and treated groups. $P<$ 0.05 was considered statistically significant. Other materials and methods not specifically described were as same as previously described (Bae et al., 2001).

\section{Results}

Effect of APAP on cell death of $\mathrm{C} 6$ glioma cells Under our current conditions, less than $10 \% \quad C 6$ glioma cells died after exposure to $2.5 \mathrm{mM}$ APAP for 24 or 48 h. In addition, less than $12.5 \%$ and $25 \%$ C6 glioma cells died after treatment with $5 \mathrm{mM}$ APAP for 24 and $48 \mathrm{~h}$, respectively. The cell death rates observed in this study were generally lower than those in our recent study (Bae et al., 2001), possibly due to the fact that more cells were used determine the APAP-induced change in the 8-oxodG level.

\section{Effect of APAP on ROS/RNS production in $\mathrm{C} 6$ glioma cells}

Previous studies suggested that APAP produces free

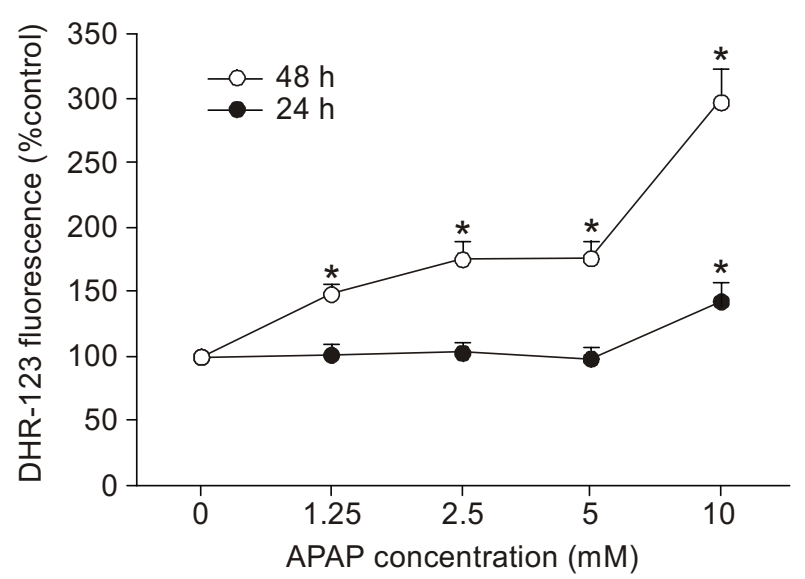

Figure 1. Time and APAP-concentration dependent ROS/RNS production. 66 cells grown in microtiter plates were treated with APAP (1.25$10 \mathrm{mM}$ ) for $24 \mathrm{~h}$ (solid circle) and $48 \mathrm{~h}$ (open circle). After APAP treatment for indicated times, conversion of DHR-123 to rhodamine-123 was determined by fluorometric analysis. *, Significantly different from the untreated control cells. radical metabolites as well as ROS (Adamson and Harman, 1993; Lores Arnaiz et al., 1995) in different cell systems. Therefore, we investigated whether APAP produces ROS/RNS in $\mathrm{C} 6$ glioma cells by using DHR-123 as a sensitive fluorescence probe, since oxidation of DHR-123 to rhodamine-123 can be mediated by peroxynitrite or $\mathrm{H}_{2} \mathrm{O}_{2}$ (Muijsers et al., 2000) and that peroxynitrite is rapidly formed by a reaction between nitric oxide and superoxide radical. DMSO (vehicle control) did not increase the ROS/RNS level, as compared with untreated control cells. APAP treatment up to $48 \mathrm{~h}$ significantly elevated the levels of ROS/RNS in concentration- and time-dependent manners (Figure 1). The rates of ROS/RNS production significantly increased at higher concentrations of APAP and longer exposure time. Approximately $76 \%$ and $198 \%$ increase in the ROS/ RNS level was observed in C6 glioma cells upon treatment with 5 and $10 \mathrm{mM} \mathrm{APAP}$ for $48 \mathrm{~h}$, respectively, as compared with the cells treated with DMSO alone. However, cells treated with $5 \mathrm{mM}$ APAP for $24 \mathrm{~h}$ did not increase the ROS/RNS level, indicating that a long exposure time is needed for the increased production of peroxides.

\section{Effect of APAP on GSH concentration in $\mathrm{C} 6$ glioma cells}

Cellular GSH level was known to change upon exposure to toxic chemicals or stressful conditions (Dimova et al., 2000; Mari and Cederbaum, 2000). Therefore, we determined whether APAP modulates the level of GSH in C6 cells. There was little difference in the GSH level between untreated cells $(0 h)$ and

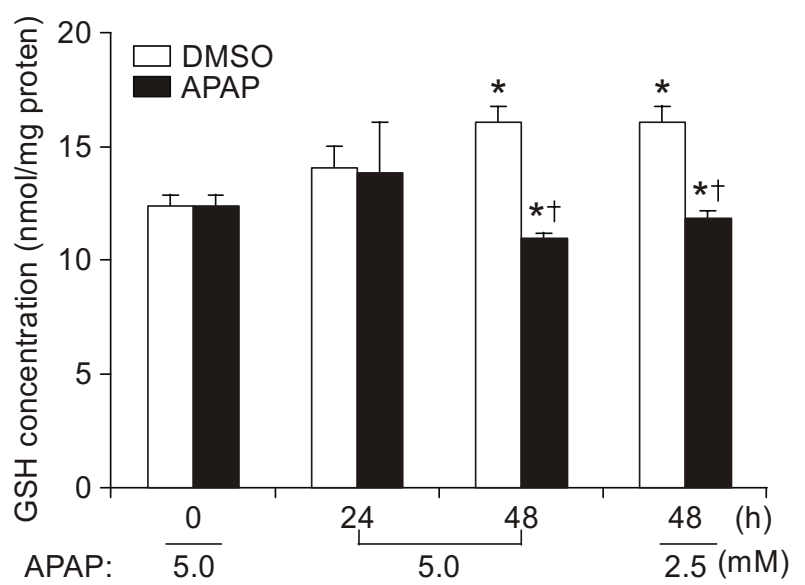

Figure 2. Time-dependent changes in the GSH levels by APAP. GSH concentrations in the whole cell extracts were determined after $\mathrm{C} 6$ cells were exposed to DMSO (open columns), $2.5 \mathrm{mM}$, or $5.0 \mathrm{mM}$ APAP (closed columns) for the indicated times. *, Significantly different from control (time 0). ${ }^{+}$, Significantly different from the values of DMSO-treated cells after the same exposure time. 
cells treated with $5 \mathrm{mM}$ APAP for $24 \mathrm{~h}$ (Figure 2). However, the GSH level after exposure to $5 \mathrm{mM}$ APAP for $48 \mathrm{~h}$ was significantly lower than that in the DMSO-exposed cells. GSH concentration was also decreased by exposure to $2.5 \mathrm{mM}$ APAP for 48 $h$, compared with the DMSO-treated cells.

\section{Effect of APAP on 8-oxodG levels in nuclear DNA}

The level of 8-oxodG in nuclear DNA was significantly elevated in a concentration- and time-dependent manner after exposure to APAP for up to $48 \mathrm{~h}$ (Figure $3)$. In general, more oxidized DNA was detected after longer exposure to APAP than shorter exposure. For instance, the level of nuclear 8-oxodG was significantly elevated after exposure to 2.5 and $5.0 \mathrm{mM}$

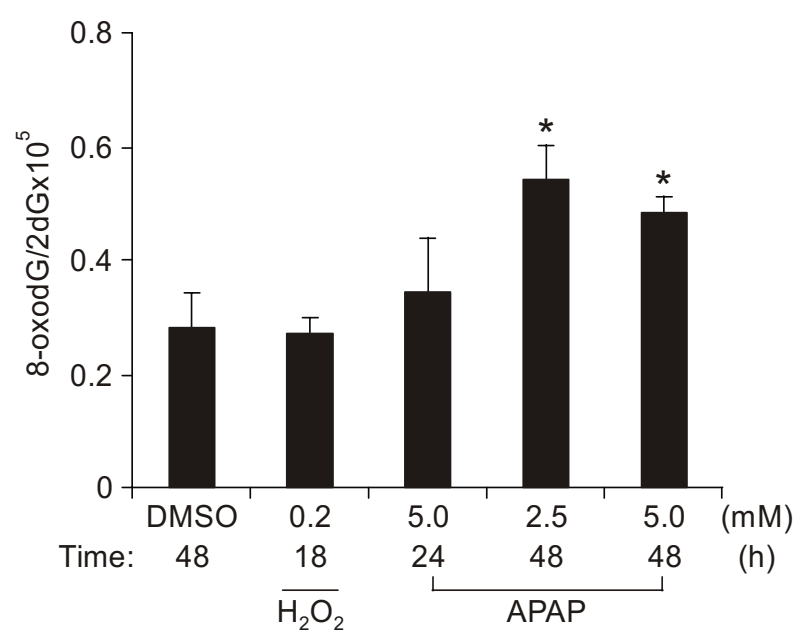

Figure 3. APAP-induced changes in the level of nuclear 8-0xodG/2dG. C6 cells were exposed to $0.2 \mathrm{mM} \mathrm{H}_{2} \mathrm{O}_{2}$ for $18 \mathrm{~h}$ or different concentrations of APAP for 24 or $48 \mathrm{~h}$, as indicated. The ratio of 8-oxodG to $2^{\prime}-d G$ in the nucleus was then determined by the method described under Materials and Methods. *, Significantly different from the DMSOtreated cells.
APAP for $48 \mathrm{~h}$, compared to the DMSO-treated control (Figure 3). In contrast, $5.0 \mathrm{mM} \mathrm{APAP}$ for $24 \mathrm{~h}$ and $0.2 \mathrm{mM} \mathrm{H}_{2} \mathrm{O}_{2}$ for $18 \mathrm{~h}$ did not increase the nuclear 8-oxodG level.

\section{Effect of APAP on nuclear 8-oxodG incision activity, Ogg1 protein and mRNA levels}

To understand the reason why APAP increased the nuclear 8-oxodG level, we determined the nuclear 8oxodG incision activity. Densitometric analysis showed that the nuclear 8-oxodG incision activity was significantly decreased by $45 \%$ and $50 \%$ after treatment with 2.5 and $5 \mathrm{mM}$ APAP for $48 \mathrm{~h}$, respectively, as compared with that of the DMSO-treated cells (Figure 4). Treatment of C6 cells with $5 \mathrm{mM}$ APAP for 24 h slightly $(16 \%)$ decreased the nuclear 8-oxodG incision activity, whereas DMSO or $0.2 \mathrm{mM} \mathrm{H}_{2} \mathrm{O}_{2}$ did not change the activity in the nucleus (data not shown).

Because of the reduction in the 8 -oxodG incision activity after APAP treatment, we then measured the level of Ogg1 protein in the nucleus from APAPtreated $\mathrm{C} 6$ cells by immunoblot analysis. One major immunoreactive band (apparent $M_{r} 38.7 \mathrm{kDa}$ ), similar to the size of the rat Ogg1 protein (Prieto Alamo et al., 1998) and human Ogg1 protein (Lee et al., 2003), was detected in the nucleus from untreated control, $\mathrm{H}_{2} \mathrm{O}_{2-}$, or DMSO-treated cells (Figure $5 \mathrm{~A}$ ), along with another minor band $\left(M_{r}\right.$ about $\left.33.0 \mathrm{kDa}\right)$. However, there was little difference in the density of both 38.7 and $33.0 \mathrm{kDa}$ bands among the untreated control, $\mathrm{H}_{2} \mathrm{O}_{2-}$, and DMSO-treated cells (Figure 5A). For instance, treatment with $0.2 \mathrm{mM} \mathrm{H}_{2} \mathrm{O}_{2}$ did not reduce the level of nuclear Ogg1 protein. In contrast, treatment with $5 \mathrm{mM}$ APAP for $48 \mathrm{~h}$ virtually abolished the 38.7 and $33 \mathrm{kDa}$ proteins (Figure $5 \mathrm{~A}$ ), whereas these proteins were still detected after exposure to $5 \mathrm{mM}$ APAP for $24 \mathrm{~h}$ (data not shown). However, the decreased Ogg1 protein did not result from the reduced level of Ogg1 mRNA because neither APAP nor $\mathrm{H}_{2} \mathrm{O}_{2}$ significantly changed the levels of $\mathrm{Ogg} 1$

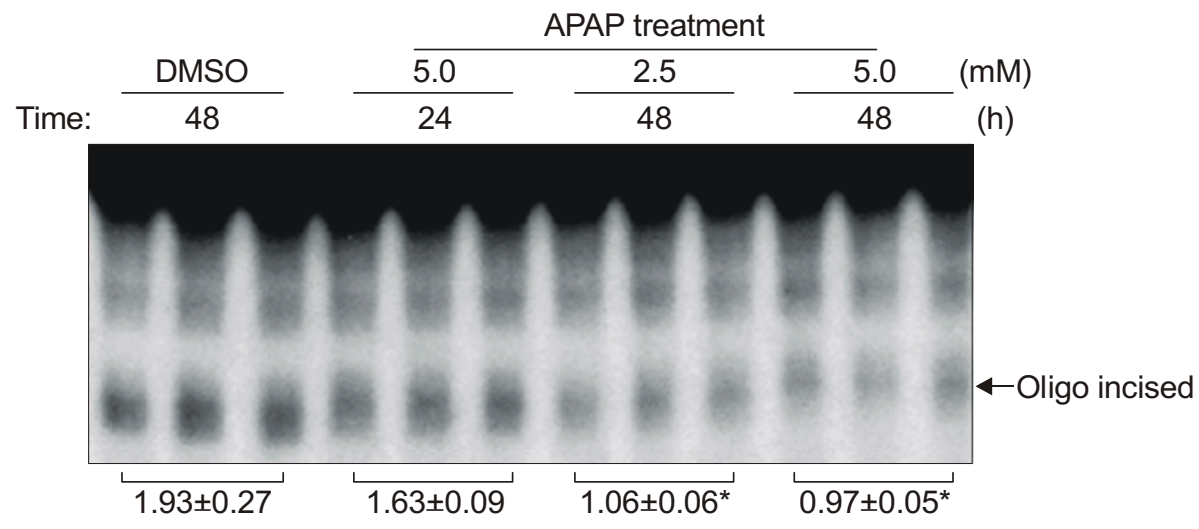

Figure 4. Effect of APAP on the 8oxodG incision activity. Activity of 8oxodG incision was determined for the nuclear extracts prepared from $\mathrm{C} 6$ cells exposed to DMSO or different concentrations of APAP for the indicated times. Autoradiographic results and arbitrary densities of the cleaved 10-mer oligo bands representing the 8-oxodG incision activity are presented. *, Significantly different from the DMSO-treated samples, $n=3$ for each treatment. 

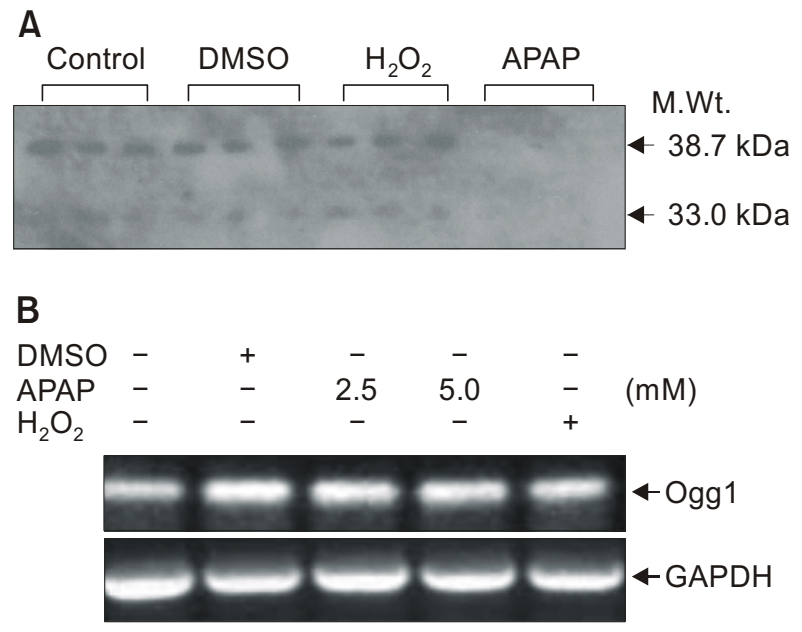

Figure 5. Effect of APAP on the levels of nuclear Ogg1 protein and mRNA. (A) The nuclear extracts were prepared from $\mathrm{C} 6$ cells exposed to DMSO, $0.2 \mathrm{mM} \mathrm{H}_{2} \mathrm{O}_{2}$ for $18 \mathrm{~h}$, or $5 \mathrm{mM} \mathrm{APAP}$ for $48 \mathrm{~h}$. Equal amounts of the nuclear extract ( $30 \mathrm{mg}$ protein/lane) were subjected to SDS-polyacrylamide gel electrophoresis followed by immunoblot analysis for $0 \mathrm{gg} 1$ protein, $n=3$ for each treatment. (B) The levels of Ogg1 and GAPDH mRNA in $\mathrm{C} 6$ cells treated differently, as indicated, were determined by RT-PCR. The primers and conditions used for amplification of Ogg1 (503 bp) and GAPDH (304 bp) were described (Tsurudome et al., 1999). PCR-amplified DNA (in $10 \mathrm{ml}$ of PCR mixture) was separated on $1 \%$ agarose gel and visualized under UV illumination. The correct size of each PCR product was verified with 100 bp-DNA ladder.

transcript determined by RT-PCR analysis (Figure $5 B)$. These results suggest that large doses of APAP can reduce the Ogg1 protein content, mainly by affecting the protein itself without changing its mRNA level.

\section{Discussion}

In this study, we investigated the production of ROS/ RNS and subsequent DNA modification in C6 glioma cells by a large dose $(5 \mathrm{mM})$ of APAP, which is the same concentration used by other investigators (Dai and Cederbaum, 1995; Holownia et al., 1997). Our current data clearly showed that APAP significantly increased the levels of ROS/RNS and nuclear 8oxodG, a marker for oxidative DNA damage. The APAP-induced elevation of nuclear 8-oxodG level is particularly of interest because of the presence of multiple defense mechanisms against oxidative DNA damage in the nucleus (Ames, 1989). The defense system include: nuclear compartmentalization away from the mitochondria where ROS are mainly produced; the presence of histone and polyamines that protect DNA from ROS-induced oxidative damage; and the presence of many different DNA repair en- zymes in the nucleus. Therefore, the elevation of oxidized DNA observed in C6 cells may be due to the following: increased production of ROS/RNS and reactive metabolites of APAP including $N$-acetyl- $p$ benzoquinoneimine (NAPQI) through cytochrome P450mediated metabolism; decreased levels of antioxidants including $\mathrm{GSH}$; and substantial reduction in the activity of nuclear Ogg1 protein, one of the major DNA repair enzymes. However, the elevated 8-oxodG level most likely results from an indirect, secondary effect of the significant reduction in Ogg1 DNA repair enzyme activity and content through interaction with reactive metabolites of APAP, because $\mathrm{H}_{2} \mathrm{O}_{2}$, a strong oxidant used as a negative control, neither elevated the level of nuclear 8-oxodG (Figure 3) nor altered the 8-oxodG incision activity or Ogg1 content (Figure 4 and 5). Furthermore, peroxynitrite itself did not elevate the 8-oxodG level (Uppu et al., 1996). Our results are in agreement with the recent report that the inactivation of the Ogg1 gene lead to accumulation of 8-oxodG in mice (Minowa et al., 2000).

The question whether large doses of APAP causes oxidative DNA damage seems unresolved due to conflicting reports. For instances, Flaks and colleagues (1983 and 1985) reported that APAP can increase the mutation rates through oxidative damage. In contrast, many other reports suggest that APAP is considered safe and non-mutagenic (for a review, see Bergman et al., 1996). These conflicting reports may derive from differences in: experimental models, route and dose of APAP administration, pre-existing conditions of host cells or animals, target tissues examined, etc. However, it is unlikely that low, therapeutic doses of APAP cause oxidative DNA damage, partly based on our current results about the relatively high concentration of APAP and long exposure time needed to observe significant changes in the 8-oxodG level. Furthermore, APAP treatment for $48 \mathrm{~h}$ only partially inhibited the nuclear 8-oxodG incision activity. These results, therefore, strongly indicate that another DNA repair enzyme(s) other than Ogg1 must be present in the nucleus and that APAP did not seem to affect the activity of this DNA repair enzyme, because of the $50 \%$ reduction in the 8 -oxodG incision activity (Figure 4) despite the near-complete depletion of Ogg1 protein (Figure 5A) after APAP exposure.

It would be of interest how the Ogg1 protein was depleted upon exposure to APAP. Our RT-PCR results (Figure $5 \mathrm{~B}$ ) clearly demonstrated that the loss of Ogg1 protein does not result from the reduction in Ogg1 mRNA content. These results indicate that translation of Ogg1 mRNA into its protein may be markedly suppressed by APAP. Alternatively, the APAP-induced depletion of Ogg1 protein may result from interaction of Ogg1 protein with the reactive metabolites of APAP such as NAPQI, which is pro- 
duced during and after P450-mediated APAP metabolism. The NAPQI-Ogg1 protein adduct may become so different from the unmodified Ogg1 protein that it may be more susceptible to proteolytic degradation than the original protein. In contrast, $\mathrm{H}_{2} \mathrm{O}_{2}$, a strong oxidant which does not produce a protein adduct, did not decrease the Ogg1 content (Figure 5A). Furthermore, the possibility of NAPQI-Ogg1 protein adduct is consistent with the well-established interaction of APAP or NAPQI with various cellular proteins through their cysteinyl-SH moiety (Streeter et al., 1984). For instance, APAP and its metabolites can bind many proteins and thereby decrease their catalytic activities. These include: N-10-formyl-tetrahydrofolate dehydrogenase (Pumford et al., 1997), glutamate dehydrogenase (Halmes et al., 1996), and aldehyde dehydrogenase (Landin et al., 1996). Alternatively, APAP or its reactive metabolites including NAPQI may interact with another amino acid residues of the Ogg1 protein (Arai et al., 1997), producing chemically damaged proteins, which become more susceptible to ubiquitindependent and independent proteolytic degradations, as recently reviewed (Goldberg, 2003). However, the production of NAPQI-Ogg1 protein adduct and the mechanism of subsequent degradation remain to be studied.

We observed that APAP diminished the nuclear 39 and $33 \mathrm{kDa}$ proteins recognized by the rabbit antimouse Ogg1 antibody, indicating the same epitope between the two immunoreactive proteins. It is possible that the $33 \mathrm{kDa}$ protein represented an alternatively sliced protein of rat Ogg1 gene, as in the case of the multiple Ogg1 isoforms derived from alternative splicing of the human Ogg1 mRNAs (Nishioka et al., 1999). The presence of alternatively spliced Ogg1 gene products in C6 glioma cells needs to be studied in the future.

In summary, APAP in large doses can cause accumulation of 8-oxodG in nuclear DNA of $\mathrm{C} 6$ glioma cells partly through significant reduction of the Ogg1 DNA repair enzyme, which results from the increased production of reactive metabolites and oxidative stress accompanied with a reduced glutathione level.

\section{Acknowledgement}

We thank Dr. Norman Salem, Jr. for his support throughout this study. We also wish to thank Drs. Phillip J. Brooks and Van Nguyen for their critical readings and comments.

\section{References}

Adamson GM, Harman AW. Oxidative stress in cultured hepatocytes exposed to acetaminophen. Biochem Pharmacol

\section{3;45:2289-94}

Ames BN. Endogenous oxidative DNA damage, aging, and cancer. Free Radic Res Commun 1989;7:121-8

Arai K, Morishita K, Shinmura K, Kohno T, Kim SR, Nohmi T, Taniwaki M, Ohwada S, Yokota J. Cloning of a human homolog of the yeast OGG1 gene that is involved in the repair of oxidative DNA damage. Oncogene 1997;14:2857-61

Bae MA, Pie JE, Song BJ. Acetaminophen induces apoptosis of $\mathrm{C} 6$ glioma cells by activating the c-Jun $\mathrm{N}$-terminal protein kinase-related cell death pathway. Mol Pharmacol 2001;60: 847-56

Bergman K, Muller L, Teigen SW. The genotoxicity and carcinogenicity of paracetamol: a regulatory review. Mutat Res 1996;349:263-88

Boiteux S, Radicella JP. The human OGG1 gene: structure, functions, and its implication in the process of carcinogenesis. Arch Biochem Biophys 2000;377:1-8

Croteau DL, ap Rhys CMJ, Hudson EK, Dianov GL, Hansford RG, Bohr VA. An oxidative damage-specific endonuclease from rat liver mitochondria. J Biol Chem 1997;272: 27338-44

Dai $Y$, Cederbaum Al. Cytotoxicity of acetaminophen in human cytochrome P4502E1-transfected HepG2 cells. J Pharmacol Exp Ther 1995;273:1497-505

Dimova S, Hoet PHM, Nemery B. Paracetamol (acetaminophen) cytotoxicity in rat type II pneumocytes and alveolar macrophages in vitro. Biochem Pharmacol 2000;59:1467-75

Flaks A, Flaks B. Induction of liver cell tumors in IF mice by paracetamol. Carcinogenesis 1983;4:363-8

Flaks B, Flaks A, Shaw APW. Induction by paracetamol of bladder and liver tumors in the rat. Acta Path Microbiol Immunol Scand 1985;93:367-77

Geng J, Strobel HW. Identification of cytochromes P450 1A2, $2 \mathrm{~A} 1,2 \mathrm{C} 7,2 \mathrm{E} 1$ in rat glioma $\mathrm{C} 6$ cell line by $\mathrm{RT}-\mathrm{PCR}$ and specific restriction enzyme digestion. Biochem Biophys Res Commun 1993;197:1179-84

Geng J, Strobel HW. Identification of inducible mixed function oxidase system in rat glioma C6 cell line. J Neurochem 1995;65:554-63

Goldberg AL. Protein degradation and protection against misfolded or damaged proteins. Nature 2003;426:895-9

Holownia A, Mapoles J, Menez JF, Braszko JJ. Acetaminophen metabolism and cytotoxicity in PC12 cells transfected with cytochrome P4502E1. J Mol Med 1997; 75:522-7

Halmes NC, Hinson JA, Martin BM, Pumford NR. Glutamate dehydrogenase covalently binds to a reactive metabolite of acetaminophen. Chem Res Toxicol 1996;9:541-6

Krokan HE, Standal R, Slupphaug G. DNA glycosylases in the base excision repair of DNA. Biochem J 1997;325:1-16

Lan J, Henshall DC, Simon RP, Chen J. Formation of the base modification 8-hydroxyl-2'-deoxyguanosine and DNA fragmentation following seizures induced by systemic kainic acid in the rat. J Neurochem 2000;74:302-9

Landin JS, Cohen SD, Khairallah EA. Identification of a 54- 
$\mathrm{kDa}$ mitochondrial acetaminophen-binding protein as aldehyde dehydrogenase. Toxicol Appl Pharmacol 1996;141:299307

Lee YS, Lee $\mathrm{KH}$, Chung MH. Expression of hOgg1 protein during differentiation of HL-60 cells. Exp Mol Med 2003; 35:98-105

Lores Arnaiz S, Llesuy S, Cutrin JC, Boveris A. Oxidative stress by acute acetaminophen administration in mouse liver. Free Radic Biol Med 1995;19:303-10

Mari M, Cederbaum AI. CYP2E1 overexpression in HepG2 cells induces glutathione synthesis by transcriptional activation of g-glutamylcysteine synthetase. J Biol Chem 2000;275: 15563-71

Minowa O, Arai T, Hirano M, Monden $\mathrm{Y}$, Nakai S, Fukuda M, Itoh M, Takano H, Hippou $Y$, Aburatani H, Masumura K, Nohmi T, Nishimura S, Noda T. Mmh/Ogg1 gene inactivation results in accumulation of 8-hydroxyguanine in mice. Proc Natl Acad Sci USA 2000;97:4156-61

Muijsers RBR, van den Worm E, Folkerts G, Beukelman CJ, Koster AS, Postma DS, Nijkamp FP. Apocynin inhibits peroxynitrite formation by murine macrophages. Brit $\mathrm{J}$ Pharmacol 2000;130:932-6

Nishioka K, Ohtsubo T, Oda H, Fujiwara T, Kang DC, Sugimachi K, Nakabeppu Y. Expression and differential intracellular localization of two major forms of human 8-oxoguanine DNA glycosylase encoded by alternatively spliced OGG1 mRNAs. Mol Biol Cell 1999;10:1637-52

Prieto Alamo MJ, Jurado J, Francastel E, Laval F. Rat 7,8dihydro-8-oxoguanine DNA glycosylase: substrate specificity, kinetics and cleavage mechanism at an apurinic site. Nucl Acids Res 1998;26:5199-202

Pumford NR, Halmes NC, Martin BM, Cook RJ, Wagner C, Hinson JA. Covalent binding of acetaminophen to $\mathrm{N}-1$-formyltetrahydrofolate dehydrogenase in mice. J Pharmacol Exp Ther 1997;280:501-5

Scott AD, Neishabury M, Jones DH, Reed SH, Boiteux S, Waters R. Spontaneous mutation, oxidative DNA damage, and the roles of base and nucleotide excision repair in the yeast Saccharomyces cerevisiae. Yeast 1999;15:205-18

Seeff LB, Cuccherini BA, Zimmerman HJ, Adler H, Benjamin SB. Acetaminophen hepatotoxicity in alcoholics - a therapeutic misadventure. Ann Int Med 1986;104:399-404
Shayiq RM, Roberts DW, Rothstein K, Snawder JE, Benson $W$, Ma X, Black M. Repeat exposure to incremental doses of acetaminophen provides protection against acetaminopheninduced lethality in mice: An explanation for high acetaminophen dosage in humans without hepatic injury. Hepatology 1999;29:451-63

Souza-Pinto NC, Croteau DL, Hudson EK, Hansford RG, Bohr VA. Age-associated increase in 8-oxo-deoxyguanosine glycosylase/AP lyase activity in rat mitochondria. Nucl Acids Res 1999;27:1935-42.

Streeter AJ, Dahlin DC, Nelson SD, Baillie TA. The covalent binding of acetaminophen to protein. Evidence for cysteine residues as major sites of arylation in vitro. Chem Biol Inter 1984;48:349-66

Tani M, Shinmura K, Kohno T, Shiroishi T, Wakana S, Kim SR, Nohmi T, Kasai H, Takenoshita S, Nagamachi Y, Yokota J. Genomic structure and chromosomal localization of the mouse Ogg1 that is involved in the repair of 8-hydroxyguanine in DNA damage. Mamm Genomes 1998;9:32-7

Thomas SH. Paracetamol (acetaminophen) poisoning. Pharmacol Ther 1993;60:91-120

Tsurudome $\mathrm{Y}$, Hirano T, Yamato $\mathrm{H}$, Tanaka I, Sagai M, Hirano $\mathrm{H}$, Nagata $\mathrm{N}$, Itoh $\mathrm{H}$, Kasai $\mathrm{H}$. Changes in levels of 8-hydroxyguanine in DNA, its repair and OGG1 mRNA in rat lungs after intratracheal administration of diesel exhaust particles. Carcinogenesis 1999;20:1573-6

Uppu RM, Cueto R, Squadrito GL, Salgo MG, Pryor WA. Competitive reactions of peroxynitrite with 2'-deoxyguanosine and 7,8-dihydro-8-oxo-2'-deoxyguanosine (8-oxodG): relevance to the formation of 8 -oxodG in DNA exposed to peroxynitrite. Free Radic Biol Med 1996;21:407-11

Whitcomb DC, Block GD. Association of acetaminophen hepatotoxicity with fasting and ethanol use. JAMA 1994;272: 1845-50

Wiseman $\mathrm{H}$, Halliwell B. Damage to DNA by reactive oxygen and nitrogen species: role in inflammatory disease and progression to cancer. Biochem J 1996;313:17-29

Wood RD. DNA repair in eukaryotes. Annu Rev Biochem 1996;65:135-67 